\title{
Institutional Structure, Social Function, and the Shakespeare Repertoire in Hungary after 1989-1990
}

Péter P. Müller

\begin{abstract}
The article discusses the framework of Hungarian Shakespeare productions after 1989-1990. Although the social function and circumstances of culture have changed, theatre was able to preserve its position, as its institutional structure remained almost the same as before. The paper studies the major Hungarian Shakespeare directors in the $20^{\text {th }}$ century, following which it deals with the relation of companies founded after 1989 to Shakespeare. Afterwards the paper shows the tendencies in the frequency of Shakespeare productions, presents the data of companies with relevant Shakespeare repertoires, and provides a list of Shakespeare plays produced in Hungarian theatres. Finally, awards given to Shakespeare productions are listed and developments in translation are outlined.
\end{abstract}

\section{Key words}

theatre structure, Shakespeare canon, favoured and neglected plays, significant directors and companies, new translations 


\section{Structural features}

Like elsewhere in the region, during 1989-1990 in Hungary the swift erosion and collapse of the Socialist system was taking place. The political change from dictatorship to parliamentary democracy was accompanied by crucial economic changes, and the society witnessed the immediate spread of capitalist economy. Nationalised properties were privatised, local governments were set up in the settlements, and cultural spheres and institutions found themselves in a completely new situation. This significant change in the status and institutional conditions of culture included a growing insecurity in financing, a decrease in funding, and the waning - sometimes vanishing - interest of the public towards certain cultural fields. As political interests could now be articulated directly, literature and the arts lost their special function in the daily fight for liberty. Moreover, the arrival of a market economy turned the previous forms of financial support upside down. Sales of books and tickets along with other such direct forms of income became the cornerstone of culture in the new system, in contrast with the ideologically controlled but financially secure decades of Socialism. Book publishing, filmmaking, music, and the fine arts all went through significant structural and financial changes. The theatrical system, however, continues to preserve a version of the Socialist theatrical model set up in 1949 both in terms of structure (the association of a building, a company and a repertoire), as well as financing (after 1949 based on a shared subsidy from the state and the local governments).

Compared to the rapid upheavals in society, politics, and economy as well as other changes in everyday life, it seems that in the theatre essentially the same people do the same things in the same place in the same way as was done in the previous period. Only contracts for actors took on new forms, as many actors were no longer paid as public servants, but as individual entrepreneurs or operators of small businesses who regularly sent an invoice to the theatre.

The Hungarian theatre system that survived the collapse of Socialism was set up in 1949 after the Communist takeover, when all theatres were nationalised following the Soviet model created in 1919. The change in Hungary in 1949 - when the state became the funder of all theatres - had further consequences, i.e., permanent companies were set up, all received their own theatre building, and they started to produce shows and perform in the repertoire system. At the same time, temporary and private groups were prohibited, and the state gained total control over all theatres, as was the case with all other spheres of society. The new theatre structure had two seemingly opposing consequences, financial safety, and political defencelessness (MÜLLER 2000).

The theatres had to pay a price for maintaining the Socialist institutional structure after 1989-1990. What had first seemed a financially and creatively stable strategy after a while merely served to continue the dependence on political power as determined by the ruling parties at both the national and local governmental level. This continues to be true, although a newly visible structural phenomenon has appeared on the margins of the dominant structure: the money divided between the theatres after a while began to reach groups and companies beyond the major structure, but the subsidy given to 
these latter groups has been as marginal as their structural position. This latter group of independent theatres/companies have often produced more significant productions than the official professional organisations.

As Hungarian culture has been invaded by the rules of the capitalist market, consequences also soon emerged regarding the quality, function, and aesthetic mission of theatres. This process already had begun in the mid-1980s with the case of a theatre in Budapest which previously had exclusively performed classic and contemporary prose plays. Changing its repertoire and profile into a musical theatre, the Madách Theatre became the forerunner of capitalist theatre in Hungary with its dedication to Andrew Lloyd Webber's oeuvre. In proceeding further along this track in the past decades, the example of this theatre demonstrates in itself the paradox of the structural anomalies of the Hungarian theatre system and the way governmental politics have come to handle the financing of the professional companies. A typical commercial theatre in London or elsewhere in the West would be a business enterprise with one goal of producing profit for the investors, but in the Hungarian system it is a state financed company. After 1989-1990, several theatres turned towards a commercial profile in terms of their program and style, e.g., omitting Shakespeare from their repertoire (MÜLLER 2011: 127). Shakespeare arrived into Hungarian culture at the turn of the $18^{\text {th }}$ and $19^{\text {th }}$ century together with his cult in which he is seen as a serious writer as opposed to an author of light entertainments. This image has not changed in spite of his brilliant comedies. In Hungarian culture, traditionally certain genres and artistic forms (e.g., operetta, farce, cabaret, etc.), and theatres with a commercial profile are not trusted to be able to create high quality productions of serious authors, like Shakespeare.

\section{Major Shakespeare directors in the $\mathbf{2 0}^{\text {th }}$ century}

Before arriving at the period after $1989-1990$, it is worth taking a glance at the $20^{\text {th }}$ century tradition of Shakespeare productions in Hungary, if only to refer to a few features and tendencies. There is a terminological issue to be clarified here about the use of the term director. In most cases in the $20^{\text {th }}$ and $21^{\text {st }}$ centuries in Hungary, theatres were led by an individual who was both artistic and managing director. Between 1919 and 1949, Shakespeare's plays appeared exclusively on the National Theatre's programme in the country. It is true that countryside theatres also produced Shakespeare, but only rarely and occasionally, with a less significant impact on Hungarian theatre history (GAJDÓ 2005: 729-770). For these groups, Shakespeare was one of several playwrights forced into the rapidly changing repertoire, with works appearing on the programme for two or three nights, and the actors performing from routine, standing in front of the prompt-box, often waiting for cues.

The director with the largest number of Shakespeare productions in this 30-year period was Sándor Hevesi (1873-1939), artistic and managing director of the National Theatre between 1922 and 1932. Hevesi directed 40 Shakespeare productions, organising them into cycles in 1923, 1926, and 1931. Within the framework of this 
project, nearly the complete dramatic oeuvre of Shakespeare was produced. The project was greeted enthusiastically by critics. Hevesi was familiar with the tendencies of contemporary theatre, e.g., the works of such innovators of directing as Otto Brahm, Max Reinhardt, and Edward Gordon Craig. Hevesi's Shakespeare productions were strong in terms of visuality and dramaturgy, with actor performances closely controlled (SZÉKELY 2005: 244-246). Hevesi was also a scholar; after World War I he published a collection of essays entitled The Real Shakespeare (HEVESI 1920). 'He was much influenced by the theories of Gordon Craig' (HARTNOLL 1967: 442) with whom he had an intensive correspondence. Craig dedicated his famous essay, 'The Actor and the Übermarionette' to two people, 'the actors de Vos and Sándor Hevesi' (CRAIG 1908: 3). The correspondence between Hevesi and Craig was published in a bilingual (English and Hungarian) edition (HEVESI 1991). The next noteworthy director to acknowledge is Tamás Major (1910-1986) with 29 Shakespeare productions, out of which he directed 27 for the National Theatre, where he was a managing director and artistic director for almost two decades starting in 1945. His first Shakespeare production as director was Much Ado About Nothing in 1940 with a reprise in 1946, both at the National Theatre. The majority of his Shakespeare productions were staged in the 1950s and 1960s. He was also a leading actor throughout his career, with some memorable performances in the roles of Shylock, Iago, Hamlet, Richard III, and King Lear (see KOLTAI 1986).

If we move forward to those artists who directed the most Shakespeare after 19891990, the first one to be mentioned is József Ruszt (1937-2005), with 21 productions out of which he directed nine in or after 1989. In the 1960s Ruszt was influenced by Grotowski and ritual theatre, principles of which he applied in his productions. Péter Valló (b. 1950) was a representative of stage realism, directing 16 Shakespeare productions, 13 of them after 1989.

Gábor Zsámbéki (b. 1943) follows with twelve Shakespeare productions, seven of them in 1989 and afterwards, all at the Katona József Theatre. Zsámbéki has been an outstanding director since the 1970s with his micro-realistic productions of plays both from the classical repertoire and from contemporary dramatists. Until 2010 Zsámbéki was an artistic director (after 1982) and later also managing director (after 1989) of Katona, the leading Hungarian art theatre. Representing Katona, from 1989 to 2008 he was a member of the Union of the Theatres of Europe, where he served as its president from 1998 to 2004. László Bocsárdi (b. 1958) also directed twelve Shakespeare productions. Since 1999 Bocsárdi has directed all the productions he has been associated with, mostly in Transylvania (Romania) with Hungarian language theatre companies, but also at the Gyula Castle Theatre and the National Theatre in Budapest. The works of Bocsárdi have strong visual compositions; he uses stylised movements, and images rule over words; in this he is related to the Romanian theatre tradition. Beginning in 1998, Róbert Alföldi (b. 1967) has directed eleven Shakespeare productions in Hungary (as well as other productions abroad). He was the managing director of the National Theatre from 2008 to 2013. His style can be described as postmodernist, mixing various media and styles to induce shocking effects. Starting his career as an actor, he performed Richard III, Macbeth, Puck, Romeo, Iago, Cornwall, Malvolio, and, most 
recently, Richard III for a second time in 2018 in an award-winning production. (See below in the section of Awards for Shakespeare productions.)

With fewer than ten productions in total among contemporary and active directors, we find Sándor Zsótér (b. 1961) with nine stagings of Shakespeare. Zsótér is known for his subversive approach to the dramatic text; he deconstructs stage realism, combining different registers, styles, and genres. In 2013 he directed a Hamlet with his actors' class at the University of Theatre and Film Arts in a production in which all eleven members of the cast appeared in several, often cross-gender roles. Gábor Tompa (b. 1957), who resides in Cluj, Romania, has directed eight Shakespeare productions so far. Tompa has been the artistic and managing director of the Hungarian Theatre of Cluj since 1990. Since 2006 he has been a member of the Union of the Theatres of Europe, leading his theatre toward membership in this organisation in 2008. Tompa was elected president of the Union in 2018. He has taught directing at the University of California San Diego since 2007. His latest Shakespeare work is a production of The Merchant of Venice (2018) which takes place in a cold world of modern technology where, in contrast with the circumstances, extreme passions are raging. The production received the best production award of the 2018-2019 season by the Romanian Theatre Association (UNITER) in 2019. During his career, he has received awards for best director and best production eight times in Romania.

\section{An overview of significant companies founded after 1989 and their relation to Shakespeare}

If we turn from the individual directors to theatre companies, it is first worth taking a look at those groups which were founded after 1989 to investigate whether Shakespeare's oeuvre inspired their artistic programme. The change of the politicaleconomic system after 1989 in the cultural field included the foundation of several new theatre companies. Here I am not referring to those countryside theatres that were established on the same basis as the majority of state and local governmentowned theatres, but to regions that did not have a permanent theatre before and who founded an organisation in the county capital, often developing from the activities of amateur companies in buildings originally built as what was referred to in Central and Eastern societies as a 'House of Culture' or a 'Palace of Culture'. ${ }^{1}$ Independent theatres emerged in these centres as well, most of these in Budapest. In what follows, I refer to four companies formed in the new era, three of them clearly independent, and a fourth whose very foundation was related to Shakespeare.

Let us start with this company that got its very start from Shakespeare. Actor and director János Csányi (b. 1966) created an independent production of A Midsummer

1 A House of Culture served as a centre for cultural events of the local community, having a theatre hall with a stage and auditorium where both the local amateur company could rehearse and perform, and where professional companies could be received. 
Night's Dream with a temporary company featuring leading popular actors; a new translation was created, e.g., the artisans' scene was re-imagined. Csányi designed the set and directed the production, which became such a resounding success that the director was able to establish a new theatre company. This became the Bárka [Ark] Theatre, which began operation in 1996 and moved into its own building in 1999, yet terminated activity in 2014. Including the founding play, four Shakespeare productions were included in the repertoire of the Bárka Theatre. The fourth of these was another A Midsummer Night's Dream (2006) directed by the theatre's artistic and managing director at the time, Róbert Alföldi. In between, there were stagings of Romeo and Juliet (2003) directed by Csányi, and Hamlet (2005) staged by British director Tim Carroll. In founding Bárka, János Csányi referred back to the theatre companies and theatrical practice of Shakespearean times by inviting playwrights to the company to write exclusively for the group and for particular actors. Unfortunately, the venture born out of a Shakespeare production lasted only for a decade and a half.

The most innovative and influential independent theatre with a significant international reputation was the Krétakör [Chalk Circle] Theatre, founded by Árpád Schilling (b. 1974) in 1995. The company worked at first with no permanent venue, creating theatre productions until 2008, after which it created projects focusing on social issues. Krétakör had only one production related to Shakespeare, hamlet.ws (2007), a classroom adaptation of Hamlet performed by three actors. This project originated from Schilling's previous production at Burgtheater Wien in 2005, entitled Hamlet3, which also used three actors. Hamlet.ws was Schilling's last directing job for Krétakör before he disbanded the company and turned Krétakör into a project-based art centre and production office. In 2018 he emigrated with his family to France because of the Hungarian government's policy toward the arts. ${ }^{2}$

The Maladype Theatre was founded in 2001 by actor-director Zoltán Balázs (b. 1977). The name of the theatre means 'meetings' in the Romani Lovari language. The company has produced Shakespeare twice so far, Macbeth/Anatomy in 2013, directed by Zoltán Balázs, and Richard III in 2016, directed by Sándor Zsótér. The company includes a small group of actors; therefore they regularly use doubling in the cast. They often make significant dramaturgical changes to the text, which was the case with their two Shakespeare productions as well.

Founded in 1998, the independent group Béla Pintér and Company may seem to have nothing to do with Shakespearean texts, at least not with producing his plays. They perform exclusively works that have been written by the leader, Béla Pintér (b. 1970). The reason why I mention this company is their practice, in which a number of elements resembling performances in Shakespearean theatrical times can be found. Pintér is an actor who performs in all the productions; he also writes and directs all his plays for his company. In his productions he uses doubling, parallel plots, and other dramaturgical features reminiscent of the practice of Elizabethan theatre. He wrote exclusively for his own company until 2016, at which time he wrote and directed a play

2 This policy includes the reduction or even termination of financial sources for independent theatre groups, and public harassment and false accusation in the national media of artists who criticise the regime. 
for the Katona József Theatre (The Champion), and the next year for the same theatre he wrote and directed Tamás Ascher in Háromszék. ${ }^{3}$

Based on the example of these four independent theatre companies, it seems that for this younger generation of theatre artists starting their careers in the 1990s, Shakespeare's oeuvre has not played a significant role in their repertoire. Nevertheless, for these practitioners, ways in which theatre worked in Shakespearean times has provided an example to follow. Working as a collective, involving the writer in the process of preparing a production, interacting with the audience, and applying workshop methods have characterised their work. Although these four companies represent only a fraction of all independent theatres, it can be said that these groups and directors continue to search the way of making theatre beyond traditional Hungarian verbose, text-based, didactic performance practices. Shakespeare's dramatic oeuvre has remained in the forefront of only the professional repertoire theatres.

\section{Tendencies in the frequency of Shakespeare productions}

In the database of Hungarian theatre productions ${ }^{4}$ there are currently about 1100 Shakespeare productions registered. Information regarding older productions, i.e., from the $19^{\text {th }}$ century and the early $20^{\text {th }}$ century, is often unavailable, with not only the cast lists, etc., but even the date of the premiere missing. This is not the case with the productions after the nationalisation of theatres, i.e., after 1949. The database includes data on 1112 Shakespeare productions, 864 of them between 1949 and 2020. This could be a solid basis upon which to divide the period into two sections, before and after the 1989-1990 season. As the program for the season of 1989-1990 was prepared before the change of political system, and the new era could be described as beginning with the programs from the 1990-1991 season, I have divided the data of Shakespeare productions between these two seasons. There were 325 Shakespeare productions in the four decades between 1949 and the 1989-1990 season, and 529 productions in the three decades between the 1990-1991 season and the end of 2019. These figures show that the number of Shakespeare productions showed a considerable increase after 1990. The average annual number of Shakespeare premieres between 1949 and 1989-1990 was eight. This average more than doubled, rising to seventeen annual premieres after 1990-1991, which is a significant development. This growth in the number of Shakespeare productions can be compared to the general statistics of Hungarian theatre premieres, which also show an increase, but much less than this noticeable doubling of the Shakespeare productions. The number of 529 includes all types of theatre productions, with prose performances (500) dominating, but puppet theatre performances, ballets, and operas are also connected to Shakespeare's plays. In arriving at the statistics regarding how often each Shakespeare drama has been produced,

3 Ascher has been the artistic director of Katona since 2011. Háromszék is a county in Transylvania, Romania.

4 See https://szinhaztortenet.hu/search. 
I focus on the prose productions exclusively. For this reason, in the next section of my paper the overall number of productions will be smaller.

\section{Companies with relevant Shakespeare repertoires}

From the above discussion of independent companies, it can be seen that this increase in Shakespeare productions has taken place in the traditional professional companies. The centre of Hungarian theatrical life is in Budapest, with these three leading companies featuring a significant Shakespeare repertoire in the Hungarian capital after 1989-1990.

Vígszínház [Comedy Theatre], Budapest, is in the lead with 21 productions. The company is housed in two buildings, with the major site bearing the name Vígszínház, and the chamber theatre Pesti Színház [Theatre of Pest]. During these three decades, nineteen Shakespeare plays were on the repertoire, Love's Labour's Lost and Romeo and Juliet twice. The 21 productions were staged by nine directors, with the most by Enikő Eszenyi (six) and Péter Valló (five).

The theatre with the second largest number of Shakespeare productions in Budapest is the National Theatre, which has a long tradition of boasting Shakespeare's plays on its repertoire, as mentioned previously. The theatre has had 16 Shakespeare productions after 1989. Among these were ten different plays, three Lears, and two each of Hamlet, Richard III, The Tempest, and A Midsummer Night's Dream. Ferenc Sík staged the most of any director, with three productions.

The Katona József Theatre was founded in 1982 by members of the National Theatre. Previously the company's venue had been the chamber theatre of the National. Twelve Shakespeare plays were produced there after 1989. The theatre has two sites, with the major one bearing the name Katona, and a smaller space called Kamra [Chamber]. The twelve productions encompassed eleven different plays, with Hamlet produced twice. Seven of these premieres were directed by Gábor Zsámbéki. ${ }^{5}$

Finally, an open-air summer theatre where Shakespeare premieres have been held each year since 1991 must be mentioned. This is the Gyula Castle Theatre, at which 27 Shakespeare productions were performed from 1991 to 2016. As the temporary summer theatre has no permanent company and as the season is very short, almost all of these productions have been co-productions of the Castle Theatre with other, permanent companies, who then added the production to their repertoire. In the past couple of years the Gyula Castle Theatre has invited productions already performed elsewhere in the previous season.

This survey of Shakespeare premieres could be extended to all Hungarian companies. Without mentioning the titles of the plays, I will mention a few countryside theatres along with the number of their Shakespeare premieres after 1990. The Miskolc National Theatre: 1990-2019 = 18; the Móricz Zsigmond Theatre, Nyíregyháza: 1992-2018 = 14; 
the Szeged National Theatre: 1993-2014 = 13; the Győr National Theatre: 1992-2017 = 13; the Csokonai National Theatre Debrecen: 1993-2019 = 12; the National Hungarian Theatre of Kolozsvár (Cluj, Romania): 1991-2018 = 12; the Pécs National Theatre: 1990-2014 = 11; the Csiky Gergely Theatre, Kaposvár: 1992-2017 = 10 .

The above figures show that Shakespeare's plays are continuously on stage both in the capital and in the countryside in Hungary. In the past three decades, every year or two one of his plays were produced in all the theatres mentioned here.

\section{List of Shakespeare plays produced in Hungarian theatres}

After focusing on the companies, let us take a look at the plays which have been selected for production. Out of the 37 Shakespeare plays, some show an outstanding number of productions, while some other works have hardly any stagings or none at all.

The canonisation of certain plays from Shakespeare's dramatic oeuvre began in the late $18^{\text {th }}$ century in England primarily through more frequent theatrical productions. Later, in academic interpretations, further selections have been made, both in England and on the continent. One of the most influential steps in canonisation was A. C. Bradley's Shakespearean Tragedy (BRADLEY 1904), in which he focused on four tragedies, Hamlet, Othello, King Lear, and Macbeth as the best representatives of Shakespeare's genius, calling these tragedies 'the famous four'. Bradley's choice later came to influence both academic research interests as well as theatre decisions as to which plays to perform from the dramatic oeuvre.

Polish essayist Jan Kott also had a significant impact both on the academic and theatrical re-interpretation of Shakespeare's works with his book Shakespeare, Our Contemporary (KOTT 1964). Published in 1970 in Hungarian, the book had an immeasurable impact on the reception and staging of Shakespeare across Europe and North America. Inspired by the views and concepts of Kott, young Hungarian Shakespeare scholars such as István Géher (1940-2012) and Géza Fodor (1943-2008) began to shape a new approach to Shakespeare in the theatre from the late 1970 s on via their teaching and dramaturgical work. ${ }^{6}$ In 1972, the Royal Shakespeare Company went on a world tour with their A Midsummer Night's Dream directed by Peter Brook, visiting several Eastern European cities, including Budapest in a production influenced by Kott's interpretation of the play. Brook, who wrote the foreword to a later edition of Kott's book, produced the comedy in an innovative way that had a significant impact on the forthcoming Shakespeare productions. After the RSC's visit, a debate began in Hungary on how to do theatre and how to perform Shakespeare (IMRE 2015). At this time, the debate was not about what to play from Shakespeare, but how to play it.

Returning to the issue of Hungarian productions, it can be seen that the rate of tragedies and comedies in the repertoire has been more or less balanced, with four plays in the lead as the most frequently produced after 1989-1990 in Hungarian theatres:

6 On Kott's work and influence in Poland and in Central Europe, see (CETERA-WLODARCZYK in this collection). 
Romeo and Juliet (61), A Midsummer Night's Dream (54), Hamlet (53), and Twelfth Night, or What You Will (41). These are followed by plays produced more than twenty times: Macbeth (28), As You Like It (26), Othello (23), The Taming of the Shrew (22), King Lear (21), and Richard III (21). Among these first ten plays, we have the four tragedies canonised by Bradley, together with Romeo and Juliet, a history play (Richard III), and four popular comedies.

The plays produced between twenty and five times are: Much Ado about Nothing (18), The Comedy of Errors (17), The Merchant of Venice (16), The Tempest (12), Measure for Measure (11), The Merry Wives of Windsor (10), Julius Caesar (6), Henry IV, Parts 1 and 2 (6), and Love's Labour's Lost (5). With these ten plays and the previous ten, we arrive at 20 plays, more than half of the Shakespearean dramatic oeuvre.

Looking at the rest of the Hungarian Shakespeare productions in the past three decades can also be instructive. In the next group of plays, the ones produced most often have four productions, with the least produced featured only once. The plays produced four times are: Troilus and Cressida (which had its first Hungarian premiere in 1966), The Winter's Tale, Timon of Athens, Pericles, and Titus Andronicus (which had its first Hungarian premiere in 1978). With less than four productions we have All's Well that Ends Well and Richard II with three; Cymbeline and Anthony and Cleopatra with two; and Coriolanus, Henry VI, Part 3, and The Two Gentlemen of Verona with one production each since 1990.

The last group includes those plays which have not been staged in the past three decades if we exclude adaptations loosely connected to the original. These are Henry V; Henry VI, Parts 1 and 2; King John, and Henry VIII. All these histories are so closely related to English events that their historical references would likely be difficult to follow by the Hungarian audience.

Several reasons might motivate a theatre to add a Shakespeare play to its repertoire. There is one aspect I would like to mention here: in Hungarian public education the compulsory curriculum in Grade 9 includes a chapter on Renaissance English theatre and dramaturgy, with two Shakespeare plays to study, Romeo and Juliet and Hamlet. In her essay, 'Teenagers in Focus - Classic/Popular Shakespeare? A Case Study of Present Day Hungarian Reception', Natália Pikli has tracked how teenagers encountered Shakespeare between 2000-2010, including the influence of textbooks. Another of her articles elsewhere also contains further details regarding Shakespeare reception (PIKLI 2011). These two plays are among the most frequently produced plays in the country. When a countryside theatre produces versions of these plays, it recruits a significant section of its audiences from secondary school students. The attendance of complete classes ensures that the production can have a long run on the repertoire, as the theatre provides the performance of a 'compulsory reading' for the schools. Of course, there might be other reasons behind the production of these two tragedies, but this is an aspect worth considering. It would be instructive to make a comparison with other countries - primarily in the Central European region - to see if their statistics of Shakespeare productions differ from the ones discussed here. 
The comparison of the number of Shakespeare's 37 plays produced within different shorter periods of time can also provide instructive results. A clear long-term tendency has been shown of the broadening of the Shakespeare repertoire, which can be demonstrated by listing just three figures. Between 1950 and 1955 eleven plays were produced from the oeuvre, between 1965 and 1970 twenty-one, and between 2000 and 2005 this number increased to twenty-six (SZABÓ 2019: 57). Roughly, a total of ten plays have not become part of the Hungarian repertoire, a fact that seems to be connected to the themes of the plays and their general position in the Shakespeare canon as being lesser known both for the theatre makers and for the public.

\section{Awards for Shakespeare productions}

The Theatre Critics' Guild began to present awards in several categories for theatre productions after the 1979-1980 season in the autumn of 1980. It is not necessary to give a complete list of categories, nor to compare the periods before and after 1990, as the 'before' phase comprises only a decade. Out of the major categories, only the awards for best production, best director, best leading actor, and best supporting actor will be named. These were the awards given to creators in Shakespeare productions in the past three decades:

1994 - A Midsummer Night’s Dream (János Csányi \& Company); awards: best alternative production; best actor (János Kulka); best supporting actor (Péter Scherer).

1996 - Othello (Budapest Kamaraszínház/Chamber Theatre); awards: best actor (Iván Kamarás).

1998 - The Merchant of Venice (Tivoli Theatre); awards: best director (Róbert Alföldi); best actor (Zoltán Rátóti).

1999 - Pericles (Katona Theatre); awards: best director (Sándor Zsótér)

2001 - A Midsummer Night's Dream/Britten's opera (Szeged); awards: best director (Sándor Zsótér).

2005 - Richard III (National Theatre, Budapest); awards: best actor (János Kulka); special price of Budapest (Tibor Szervét, actor for Henry IV, Radnóti Theatre).

2006 - Troilus and Cressida (Katona Theatre, Budapest); awards: best production (shared); best director (Silviu Purcărete).

2009 - The Merchant of Venice (Eger); awards: best director (Sándor Zsótér).

2010 - Othello (Vígszínház); awards: best actor (Ernő Fekete).

2012 - Hamlet (National Theatre, Budapest); awards: best supporting actor (Roland Rába).

2014 - Hamlet (Örkény Theatre); awards: best director (László Bagossy).

2018 - Richard III (Radnóti Theatre); awards: best actor (Róbert Alföldi); best supporting actor (Zsolt László).

2019 - The Merchant of Venice (Miskolc); awards: best actor (László Görög). 
Annually there have been 12-15 categories in which theatre critics have given their awards. Out of the approximately 500 Shakespeare productions after 1990, a total of 19 awards have been presented for production, directing, and acting. Therefore, it can be said that Shakespeare productions are underrepresented in the list of awards. Looking at the titles of plays among the awardees, it is noticeable that rarely produced (Pericles, Troilus and Cressida) as well as the most frequently produced plays (A Midsummer Night's Dream, Hamlet, etc.) are equally represented in this list. The rate of reoccurring names is so low that no conclusion can be drawn. Róbert Alföldi and János Kulka have received two, and Sándor Zsótér three awards in the past three decades for their contributions to Shakespeare productions.

In 2000, a private award was founded to commemorate actor Miklós Gábor (19191998), a leading actor from the 1960s on who performed several major Shakespeare characters. Established by his widow Éva Vass (1933-2019), the Miklós Gábor Award is presented annually for the best actor in a Shakespeare role in the previous season.

Out of these award-winning productions Pericles (1999) has been discussed in English by Zsuzsánna Kiss (KISS 2018). The 2014 production of Hamlet in the Örkény Theatre is reviewed in English by Natália Pikli on the Shakespeare blog (see PIKLI 2014). The 2018 production of Richard III in the Radnóti Theatre was also reviewed by Natália Pikli in English in The Theatre Times (PIKLI 2018).

\section{Translations}

Finally, there is one more aspect worth including in the analysis of how Shakespeare's presence has changed during the past decades, and that is the issue of new translations.

The first proper translations into Hungarian with literary relevance were made in the mid-1840s. Several of the most significant writers of the time, among them János Arany, Mihály Vörösmarty, and Sándor Petőfi, all primarily poets, formulated a plan to publish 22 Shakespeare plays in Hungarian. The initiative began in 1848, but only the first volume was completed due to historical-political reasons. The series All the Works of Shakespeare [Shakespeare minden munkái] became complete by 1878 in nineteen volumes. A detailed survey is given of the Hungarian Shakespeare translations, from the beginning to the end of the $19^{\text {th }}$ century by Márta Minier (2017).

During the first half of the $20^{\text {th }}$ century, the tendency for poets to translate Shakespeare continued with the work of Mihály Babits, Lőrinc Szabó, Dezső Kosztolányi, and others. A new edition of The Complete Works of Shakespeare prepared during World War II was first published in 1948 in four volumes. Then with some revisions, it was published again in 1955, 1961, and 1988. In 1992, a revised edition was released, which has been reprinted several times since then.

As most of the translations were made by major Hungarian writers, these translations became canonised as significant literary pieces, remaining for a long time 'untouchable'. Translations commissioned for particular Shakespeare premieres began to 
emerge only in the 1980s. Since 1990, several new translations have been made, sometimes by directors themselves for their own productions.

It can be said that the major translator of Shakespeare in the second half of the $20^{\text {th }}$ century was Dezső Mészöly (1918-2011), who created new Hungarian versions of Antony and Cleopatra (1946), Measure for Measure (1947), Othello (1949), Romeo and Juliet (1953), The Tempest (1960), The Winter's Tale (1965), Love's Labour Lost (1969), Much Ado About Nothing (1980), Twelfth Night (1985), King Lear (1986), and Hamlet (1996). Mészöly was primarily a translator and an essayist.

István Vas (1910-1991) translated Henry VI, Part 1, Richard III, Henry IV, Parts 1 and 2, All's Well that Ends Well, The Merchant of Venice (1948), Antony and Cleopatra (1955), and Henry V (1981). Vas was a significant poet of his time. The poet, novelist, playwright, dramaturg, and translator István Eörsi (1931-2005) created versions of A Midsummer Night's Dream (1980), Hamlet (1983), Coriolanus (1985), The Tempest (1985), and Othello (1988). Out of these three translators, it was Dezső Mészöly who translated the most Shakespearean plays, i.e., eleven, and many of his versions replaced previous canonised, classic translations.

The major translator after 1990 can be said to be linguist and poet Ádám Nádasdy (b. 1947): A Midsummer Night's Dream (1994), The Comedy of Errors (1997), Hamlet (1999), The Taming of the Shrew (2000), Romeo and Juliet (2003), Twelfth Night, Or What You Will (2005), As You Like It (2007), King Lear (2010), The Tempest (2012), Measure for Measure (2014), The Merchant of Venice (2015), and Henry IV, Parts 1 and 2 (2016-2017). The 13 Shakespeare plays translated by Nádasdy have all been at the request of theatres for a new production.

Other translators include:

Imre Szabó Stein (b. 1966): The Merchant of Venice (1998), Macbeth (2001).

András Forgách (b. 1952): King Lear (1992-1993), Antony and Cleopatra (1994).

Dezső Tandori (1938-2019): Titus Andronicus (1997), The Tempest (1999).

András Imreh (b. 1966): Henry VI, Part 3 (1999).

Szabolcs Várady (b. 1943): The Winter's Tale (2006).

György Spiró (b. 1946): Richard III (2008).

László Márton (b. 1959): Othello (2009).

Anna T. Szabó (b. 1972): The Winter's Tale (2017).

János Csányi (b. 1966): A Midsummer Night's Dream (1994), Romeo and Juliet (2004).

This incomplete list of translations demonstrates that there is no correlation between how many times a play has been translated and how often it has been put on stage. A good example is The Winter's Tale with three translations and three productions altogether. 


\section{Conclusion}

The facts and tendencies presented above show that Shakespeare has been a dominant playwright in Hungary and Hungarian speaking theatres for the past three decades. Since 1990, after Shakespeare the following non-Hungarian dramatists have had the highest numbers of productions: Chekhov (211), Molière (199), Goldoni (134), Brecht (130), Ibsen (91), Feydeau (91), Arthur Miller (82), Sophocles (64), Schiller (62), Tennessee Williams (59), just to mention the top ten.

With his 520 productions, no playwright comes close to Shakespeare's total. If we consider the most popular Hungarian playwright in terms of productions, Ferenc Molnár (1878-1952), with 228 stagings of his plays since 1990, still remains almost 300 productions behind Shakespeare. Incidentally, the total number of productions in the database between 1949 and 1989 is 13,695; from 1990 to 2020, it is 19,245. The percentage of Shakespeare productions may be small, but the rate compared to that of all other playwrights is outstanding.

As is likely the case in other European countries - most evidently the United Kingdom - in Hungary, Shakespeare's works cannot be separated from the cult that has developed around him as a historical figure as well as in terms of his oeuvre. Part of this connection between the works and the cult is the fact that his name has become a brand. For theatres, it has been easier to promote a new premiere with the name of Shakespeare than with a much lesser known contemporary dramatist, whether from Hungary or not. Nevertheless, the quantity of Shakespeare premieres does not necessarily correlate with the quality of these productions. When more than half a century ago Peter Brook described a major type of theatre in the opening chapter of his book The Empty Space, he referred to his experience of Shakespeare productions:

Of course nowhere does the Deadly Theatre install itself so securely, so comfortably and so slyly as in the works of William Shakespeare. The Deadly Theatre takes easily to Shakespeare. We see his plays done by good actors in what seems like the proper way - they look lively and colourful, there is music and everyone is all dressed up, just as they are supposed to be in the best of classical theatres. Yet secretly we find it excruciatingly boring - and in our hearts we either blame Shakespeare, or theatre as such, or even ourselves. (BROOK 1996: 8-9)

It might seem unfair to refer to Brook's diagnosis from 1968 about a significant part of Shakespearean performance as it took place then. While Brook's term 'Deadly Theatre' might safely be said to describe some of the productions behind the figures and statistics discussed here, the significant changes in Hungarian theatre must be recognised and admitted, and this also holds true for Shakespeare productions, perhaps even more so. One direction of this change has been in the establishment of theatre as an independent artistic form for which the controlling agent is the director, who can now handle even classical, canonised plays with a great measure of artistic freedom. Therefore, to refer to a production as a 'Shakespeare play' is often only partially true, as the 'original' text has gone through substantial, at times even radical, changes 
during the rehearsal process. This is true for most of those productions that have been awarded by the Theatre Critics' Guild as well as by other organisations.

If we place Shakespeare in the general context of contemporary Hungarian theatre of the past three decades, the internal changes and short-term tendencies within this period become obvious. While between 1995 and 2010 the average percentage of Shakespeare premieres within the complete number of premieres was $3.16 \%$, in the following half decade (2010-2015) this decreased to 2.36\% (SZABÓ 2019: 60). Several factors might have had an effect on such a change. If we return to the statistics of the database, it is conspicuous that in the same period the number of national premieres of brand-new Hungarian plays increased significantly. Between 2010 and 2015, there were 1210 premieres of this kind, with the most in 2016, when in one year there were 341 first shows of new Hungarian dramas. Nevertheless, it is not certainly granted that in the long run a brand-new play will become part of the repertoire. In fact, more than $90 \%$ of the plays once produced never return to the stage, disappearing through the trapdoor. One example to underline this is the case of the cycle of new Hungarian drama in the 1970s and 1980s in the National Theatre of Pécs. The period has proudly been considered as the golden age of contemporary Hungarian drama in Pécs, yet when I investigated the further fate of these plays, it turned out that after their premiere in Pécs, none of them became part of the theatrical repertoire of the country and none of them was ever produced again (MÜLLER 2008: 226).

In spite of the short life of many contemporary dramas, scripts, scenarios, and playtexts, sometimes this better serves the aim of the creators to address current social and artistic issues. These intentions have characterised many of those independent companies I have mentioned above, e.g., the Krétakör Theatre, Béla Pintér and Company, Maladype, and the Bárka Theatre. Beside these, several groups were formed in the 2010s dedicated to the Theatre in Education (TIE) movement, which specialises in participatory theatre. In addition, many professional repertoire theatres have initiated programmes and projects focusing on theatre education. These tendencies can lead these companies away from classical plays, including Shakespeare.

It cannot be declared that there have been directors in the past three decades in Hungary who have built their career on producing Shakespeare's plays, nor can this be said for any actors. We can identify neither Shakespeare-directors, nor Shakespeareactors in Hungarian theatre in the past three decades. It seems that regardless of the high amount of Shakespeare production in the past three decades, the younger generation of directors who began their career around or after 1989-1990 have had a somewhat different or less cultic connection to Shakespeare. In this approach, Shakespeare, who in the $19^{\text {th }}$ century was called by Hungarian critic Emil Ábrányi (1820-1850) 'the second-born son of God' (Ábrányi quoted in DÁVIDHÁZI 1989: 142), has become just one of many dramatists to be produced. Nevertheless, this primus inter pares remains a symbol of permanence in a world of constant change, a continuously renewable source for inspiration. 


\section{Bibliography}

BÉCSY, Tamás and György SZÉKELY (eds.). 2005. Magyar szinháztörténet 1920-1949 [History of Hungarian Theatre 1920-1949]. Budapest: Magyar Könyvklub, 2005.

BRADLEY, A. C. 1904. Shakespearean Tragedy. London: Macmillan, 1904.

BROOK, Peter. 1996. The Empty Space. New York: Touchstone, 1996 [1968].

CRAIG, Edward Gordon. 1908. The Actor and the Über-marionette. The Mask 1 (April 1908): 2: 3-15.

DÁVIDHÁZI, Péter. 1989. 'Isten másodszülöttje.' A magyar Shakespeare-kultusz természetrajza ['The Second-born Son of God.' The Natural History of the Hungarian Shakespeare Cult]. Budapest: Gondolat, 1989.

GAJDÓ, Tamás. 2005. Kísérletek a kerületi rendszer újjászervezésére és a vidéki színházi központok megteremtésére [Attempts to Reorganise the District System and to Set Up the Provincial Theatre Centres]. In Tamás Bécsy and György Székely (eds.). Magyar színháztörténet 1920-1949 [History of Hungarian Theatre 1920-1949]. Budapest: Magyar Könyvklub, 2005: 729-770.

HARTNOLL, Phyllis (ed.). 1967. The Oxford Companion to the Theatre. London: Oxford University Press, 1967.

HEVESI, Sándor. 1920. Az igazi Shakespeare [The Real Shakespeare]. Budapest: Táltos, 1920.

HEVESI, Sándor. 1991. The Correspondence of Edward Gordon Craig and Sándor Hevesi (1908-1933). Ed. by György Székely. Budapest: Hungarian Theatre Institute and Museum, 1991.

IMRE, Zoltán. 2015. A Midsummer Night's (Different) Dreams: The Royal Shakespeare Company's 1972 Tour in Eastern Europe. Theatre Survey 56 (2015): 3: 336-361.

KISS, Zsuzsánna. 2018. Between Meaning and Understanding: King Lear and Pericles on Hungarian Stages. In Jana B. Wild (ed.). Shakespeare in Between. Bratislava: VŠMU, 2018: 75-88.

KOLTAI, Tamás. 1986. Major Tamás. Budapest: Ifjúsági Lap- és Könyvkiadó, 1986.

KOTT, Jan. 1964. Shakespeare, Our Contemporary. Transl. by Bolesław Taborski. New York: Doubleday \& Company, Inc., 1964.

MINIER, Márta. 2017. Uprooting Shakespeare. A Historical Survey of Early to Institutionalised Hungarian Shakespeare Translation. In Jana Bžochová-Wild (ed.). 'In double trust'. Shakespeare in Central Europe. Bratislava: Vysoká škola múzických umení, Divadelná fakulta, 2017: 29-51.

MÜLLER, Péter P. 2000. To Change or not to Change: Stagnation and Transition in Hungarian Theatre. In Dragan Klaić and Maaike van Geijn (eds.). '...en de ton die viel in duigen...' ['...and the barrel which fell apart...']. Amsterdam: Theater Instituut Nederland, 2000: 123-125.

MÜLLER, Péter P. 2008. Színház/művészet/politika. Pécsett az 1970-es, '80-as években. [Theatre/Art/Politics. In Pécs in the 1970s and 80s]. In Péter P. Müller (ed.). Hamlettól a Hamletgépig [From Hamlet to the Hamletmachine]. Budapest: Kijárat, 2008: 213-227.

MÜLLER, Péter P. 2011. Permanence in the Process of Changing: Major Features in the Institutional Structure and Social Function of Hungarian Theatre after the F/Wall. In Attila Szabó (ed.). Theatre After the Change: And What was There Before the After?, vol. 2. Budapest: Creativ Média, 2011: 125-130.

PIKLI, Natália. 2011. Teenagers in Focus - Classic/Popular Shakespeare? A Case Study of Present Day Hungarian Reception. In Bálint Gárdos et al. (eds.). Confrontations and Interactions. Essays on Cultural Memory. Budapest, Paris, Torino: L'Harmattan, 2011: 235-255. 
PIKLI, Natália. 2014. Hamlet, Örkény Theatre, Budapest, Hungary, 21 March 2014, directed by László Bagossy. Reviewing Shakespeare. [accessed on 23.01.2021]. Available online at https:// bloggingshakespeare.com/reviewing-shakespeare/hamlet-orkeny-theatre-budapest-hungary-2014-2/.

PIKLI, Natália. 2018. 'My kingdom for a...' - What?! Andrei Şerban’s 'Richard III' at the Radnóti Theatre, Budapest. The Theatre Times (15. 12. 2018). [accessed on 23.01.2021]. Available online at https://thetheatretimes.com/my-kingdom-for-a-what-andrei-serbans-richard-iii-at-the-radnoti-theatre-budapest/.

SZABÓ, Attila. 2019. Klasszikus drámák a modern színpadon. Shakespeare és a kortárs dráma színpadi aktualitása a 20. század második felében és napjainkban [Classic Dramas on the Modern Stage. The Theatrical Topicality of Shakespeare and Contemporary Drama in the Second Part of the $20^{\text {th }}$ Century and Nowadays]. In Attila Szabó (ed.). A valós színterei [Scenes of the Real]. Budapest: PRAE.HU, 2019: 53-76.

SZÉKELY, György. 2005. A Nemzeti Színház [The National Theatre]. In Tamás Bécsy and György Székely (eds.). Magyar szinháztörténet 1920-1949 [History of Hungarian Theatre 1920-1949]. Budapest: Magyar Könyvklub, 2005: 215-312. 


\section{Péter P. Müller, PhD, dr. habil., DSc}

Department of Literary Theory and Modern Literature,

Faculty of Humanities and Social Sciences, University of Pécs

Ifjúság u. 6., 7624 Pécs, Hungary

muller.peter@pte.hu

ORCID: https://orcid.org/0000-0001-9441-2409

Péter P. Müller is a professor at the Department of Literary Theory and Modern Literature at the University of Pécs where he is the Head of the Doctoral School of Literary and Cultural Studies. He has published ten books as well as edited twelve volumes on modern European drama and theatre, Hungarian drama, theatre theory, along with theatricality and the body. 